University of Nebraska - Lincoln

DigitalCommons@University of Nebraska - Lincoln

\title{
Cytokine Responses In Whole Blood Assay In Veterans With Agriculture Work Exposures
}

J. D. J. Romberger

VA Nebraska-Western lowa Healthcare System,

J. L. Meza

University of Nebraska Medical Center,

E.C. Chickris

University of Nebraska Medical Center,

A. J. Heires

University of Nebraska Medical Center,

R. M. Zotti-Pierce

University of Nebraska Medical Center,

See next page for additional authors

Follow this and additional works at: https://digitalcommons.unl.edu/publichealthresources

Part of the Public Health Commons

Romberger, J. D. J.; Meza, J. L.; Chickris, E.C.; Heires, A. J.; Zotti-Pierce, R. M.; and LeVan, T. D., "Cytokine Responses In Whole Blood Assay In Veterans With Agriculture Work Exposures" (2012). Public Health Resources. 196.

https://digitalcommons.unl.edu/publichealthresources/196

This Article is brought to you for free and open access by the Public Health Resources at DigitalCommons@University of Nebraska - Lincoln. It has been accepted for inclusion in Public Health Resources by an authorized administrator of DigitalCommons@University of Nebraska - Lincoln. 


\section{Authors}

J. D. J. Romberger, J. L. Meza, E.C. Chickris, A. J. Heires, R. M. Zotti-Pierce, and T. D. LeVan 


\title{
Cytokine Responses In Whole Blood Assay In Veterans With Agriculture Work Exposures
}

\author{
D. J. Romberger ${ }^{1}$, J. L. Meza ${ }^{2}$, E. Chickris ${ }^{2}$, A. J. Heires ${ }^{2}$, R. Zotti-Pierce ${ }^{2}$, T. D. LeVan ${ }^{1}$, \\ ${ }^{1}$ VA Nebraska-Western lowa Healthcare System, Omaha, NE, 2 University of Nebraska Medical Center, Omaha, NE
}

Corresponding author's email: dromberg@unmc.edu

RATIONALE: Agriculture exposures are associated with increased risk of chronic obstructive pulmonary disease (COPD). Endotoxin exposure in agricultural environments is associated with lung disease. Our objective was to evaluate responsiveness to endotoxin stimulation in an in vitro

whole blood assay and its association with COPD in an agriculturally exposed cohort.

METHODS: Veterans with $\geq$ two years agricultural work exposure participated in this case-control study. Cases are veterans with COPD defined as FEV1/FVC ratio $<70 \%$ on spirometry post-bronchodilator. Controls did not have COPD as assessed by spirometry nor other significant lung conditions. Whole blood assay (WBA) was done with $2 \mathrm{ml}$ heparinized blood mixed with $2 \mathrm{ml}$ of media and stimulated with increasing doses of LPS $(0-1 \mathrm{ng} / \mathrm{ml})$. Samples were incubated at $37^{\circ} \mathrm{C}$ for 24 hours, centrifuged, supernatants harvested and frozen until assayed for cytokines by ELISA. Cytokine values were log transformed. Repeated measures ANOVA was used to examine the association between LPS dose and group (case or control) and the interaction of dose with group. All p values were adjusted for age. RESULTS: There were 272 participants, 110 cases with COPD and 158 controls. Baseline demographics (gender, age, race) were similar between cases and controls. LPS-stimulated TNF-a production showed a significant dose effect $\left(\mathrm{p}_{\mathrm{adj}}<0.0001\right)$ and a significant difference between study groups $\left(\mathrm{p}_{\mathrm{adj}}=0.0119\right)$ with controls having a greater capacity for TNF-a production than cases. There was no evidence of a significant interaction between dose and group $\left(p_{a d j}=0.0803\right)$. Tukey post hoc comparisons revealed a significant difference between cases and controls at the $0 \mathrm{ng} / \mathrm{mL}\left(p_{a d j}=0.0146\right), 0.01 \mathrm{ng} / \mathrm{mL}\left(p_{a d j}=0.0233\right)$ and $0.1 \mathrm{ng} / \mathrm{mL}\left(p_{a d j}=0.0369\right)$ LPS doses. For IL-6, there was a significant dose effect $\left(\mathrm{p}_{\mathrm{adj}}<0.0001\right)$ and a significant interaction between dose and group ( $\left.\mathrm{p}_{\mathrm{adj}}=0.0030\right)$. Post hoc comparisons revealed a significant difference between cases and controls at the $0 \mathrm{ng} / \mathrm{mL} \mathrm{LP}\left(\mathrm{p}_{\mathrm{adj}}=0.0108\right)$ and $0.001 \mathrm{ng} / \mathrm{mL}$ LPS $\left(\mathrm{p}_{\text {adj }}=0.0164\right)$ doses with COPD subjects having a greater capacity for IL-6 production.

CONCLUSIONS: In veterans with agriculture exposures, persons with COPD demonstrated increased IL- 6 at baseline and in response to endotoxin stimulation in a whole blood assay compared to those without COPD; whereas the opposite was observed with TNF-a levels.

This abstract is funded by: VA Merit Review Program (DJR \& TDL)

Am J Respir Crit Care Med 185;2012:A4657

Internet address: www.atsjournals.org 